\title{
Stan i potrzeby badań nad tradycyjnym budownictwem chłopskim w muzeach (na przykładzie łódzkiego ośrodka etnograficznego i wybranych placówek $\mathrm{z}$ terenu Polski środkowej)
}

Zainteresowanie problematyką tradycyjnego budownictwa chłopskiego ${ }^{1}$ zaowocowało licznymi pracami terenowymi oraz publikacjami. W opracowaniach dotyczących konkretnej wsi, danego regionu, obszaru całej Polski, lub nawet szerszego terytorium znajdują się bowiem pokaźne rozdziały poświęcone tej tematyce [zob. np. Moszyński 1967: 473-578; Gładyszowa 1976: 279-327]. Nie zapominajmy przy tym o publikacjach traktujących wyłącznie o tradycyjnym budownictwie chłopskim w danym regionie opartych na źródłach i wynikach badań terenowych [zob. np. Święch 2002, 2012] lub rozpatrujących to zagadnienie w szerszej perspektywie czasowej niż XIX-XX wiek z wykorzystaniem przede wszystkim źródeł pisanych [zob. np. Czajkowski 2011].

W ramach niniejszego opracowania ${ }^{2}$ uwaga zostanie skoncentrowana na przeglądzie badań nad tradycyjnym budownictwem chłopskim, które

\footnotetext{
${ }^{1} \mathrm{~W}$ niniejszym opracowaniu przyjąłem termin „budownictwo chłopskie” tj. związane z tą warstwą mieszkańców wsi. Nie jest on tożsamy z terminem „budownictwo wiejskie”, który kierowałby naszą uwagę na całokształt zabudowań wsi, a zatem także na obiekty sakralne, dworskie, przemysłowe czy rzemieślnicze.

${ }^{2}$ Artykuł stanowi rozszerzoną wersję referatu pt. O potrzebie badań nad tradycyjnym budownictwem chłopskim $w$ muzeach (na przykładzie działalności wybranych placówek z terenu Polski środkowej) wygłoszonego 21.09.2018 r. na ogólnopolskiej konferencji poświęco-
} 
prowadzono z ramienia Muzeum Archeologicznego i Etnograficznego w Łodzi na terenie środkowej Polski. W szczególności dokonane zostanie nawiązanie do prac przeprowadzonych we wsi Stobiecko Miejskie (dziś część miasta Radomska) oraz w wybranych wsiach regionu łęczyckiego. Wszystko to posłuży podjęciu próby odpowiedzi na pytanie, czy rezultaty tych badań przełożyły się na powstanie funkcjonujących placówek muzealnych lub ich oddziałów.

Początki zainteresowań tradycyjnym budownictwem chłopskim na obszarze Polski środkowej sięgają II połowy XIX wieku [np. Grajnert 1880; Karłowicz 1884: 406; Wawrzeniecki 1898; Piątkowska 1899]. Dopiero jednak w okresie międzywojennym podjęto pierwsze systematyczne prace inwentaryzacyjne. Wykonano je z ramienia ówczesnego Zakładu Architektury Polskiej Politechniki Warszawskiej w latach 1921-1946, przy czym zdecydowana większość dokumentacji powstała przed wybuchem II wojny światowej. Inwentaryzację przeprowadzano w myśl jednolitych kryteriów, dokumentując przykłady zabudowań najstarszych, typowych (czyli najczęściej ówcześnie występujących we wsi), oraz najmłodszych. Materiały te zawierają obok rzutów przyziemi i przekrojów obiektów również rysunki rozplanowania zagród, detali architektonicznych budynków oraz stosunkowo nieliczną dokumentację fotograficzną. Systematyczne sprawozdania z badań, zawierające ich program oraz katalog badanych miejscowości, były publikowane przez Franciszka Piaścika [zob. Piaścik 1932, 1935]. Nie należy zapominać także o wkładzie poszczególnych osób, jak np. związanego z Tomaszowem Mazowieckim Tadeusza Seweryna gromadzącego materiały m.in. z zakresu budownictwa na terenie Opoczyńskiego.

Znaczący przełom w badaniach nad architekturą chłopską w Polsce środkowej przyniósł dopiero okres po II wojnie światowej. W prowadzone prace włączały się kolejne ośrodki badawcze, zarówno uniwersyteckie, politechniczne, jak i muzealne oraz z kręgu Polskiej Akademii Nauk. Na polu badań nad tradycyjnym budownictwem chłopskim aktywne było także Polskie Towarzystwo Ludoznawcze oraz służby konserwatorskie. W ramach działalności tych służb opracowano szereg kart ewidencyjnych tzw. zielonych kart. Wśród szerzej zakrojonych prac wymienić należy działania związane z Polskim Atlasem Etnograficznym obejmujące obszar

nej pamięci Profesor Bronisławy Kopczyńskiej-Jaworskiej pt. Etnografie wspótczesności. Obszary, metody, perspektywy. Konferencja towarzyszyła 94. Walnemu Zgromadzeniu Delegatów Polskiego Towarzystwa Ludoznawczego. 
całej Polski środkowej, na którym trwały one od 1959 roku do połowy lat sześćdziesiątych XX wieku.

Badania terenowe, w tym nad zagadnieniami tradycyjnego budownictwa chłopskiego, prowadzone przez zespół etnograficzny Muzeum Archeologicznego i Etnograficznego w Łodzi w wytypowanych wsiach w różnych regionach Polski środkowej nie miały charakteru doraźnych działań, lecz stanowiły realizację programu badawczego sformułowanego i kierowanego przez prof. Kazimierę Zawistowicz-Adamską [zob. Zawistowicz-Adamska 1957, 1959, 1960]. Realizowano go od początku lat pięćdziesiątych XX wieku m.in. na terenie Radomszczańskiego (Włynice, Stobiecko Miejskie), Sieradzkiego (Klonowa), Rawskiego (Jasień) czy Łęczyckiego (Łęka). Duże zasługi na polu badań nad tradycyjnym budownictwem chłopskim z ramienia wspomnianej placówki posiadają jej długoletni pracownicy Bożenna Paszkowska-Wróblewska i Józef Lech. Pokłosiem ich działań badawczych są liczne publikacje dotyczące tej problematyki na obszarze środkowej Polski [zob. Paszkowska-Wróblewska 1960, 1963, 1964, 1965, 1969; Lech 1979].

Badania w Stobiecku Miejskim, wsi położonej w powiecie radomszczańskim w południowej części ówczesnego województwa łódzkiego (w granicach administracyjnych istniejących do 1975 roku), podjęto w 1959 i 1961 roku. Stobiecko Miejskie zlokalizowane było w odległości około 4 kilometrów na północny-zachód od miasta Radomska. W czasie prac terenowych wieś należącą do typu wielodrożnicy zamieszkiwało w przybliżeniu 2100 mieszkańców. Szczególną uwagę prowadzącej prace terenowe Bożenny Paszkowskiej-Wróblewskiej zwróciły obiekty tzw. budownictwa „tatarskiego”. W wyniku badań nad tego rodzaju budownictwem, których ustalenia nie będą tu szerzej prezentowane, ponieważ były one już przedmiotem publikacji, badaczce udało się udokumentować pięć w pełni oraz jedenaście częściowo zachowanych zagród [Paszkowska-Wróblewska 1963].

Drugi interesujący nas kierunek badań przeprowadzonych z ramienia Muzeum Archeologicznego i Etnograficznego w Łodzi odbył się na terenie Łęczyckiego w latach 1961-1963. Do badań wytypowana została wieś Łęka położona około $12 \mathrm{~km}$ na zachód od Łęczycy, gdzie problematyką budownictwa chłopskiego zajęła się ponownie Bożenna Paszkowska-Wróblewska. We wsi badaczka udokumentowała tam zarówno budownictwo drewniane jak i gliniane [Paszkowska-Wróblewska 1964]. Ponadto również w latach sześćdziesiątych XX wieku przedmiot jej zainteresowania stanowiło miesz- 
kalne budownictwo chłopskie wzniesione z gliny w łęczyckiej wsi Chorki³, w której przeprowadzono prace z uwagi na liczne zachowane tam tego typu obiekty [Paszkowska-Wróblewska 1969].

Temat glinianego budownictwa chłopskiego w Chorkach podjął również autor niniejszego artykułu w 2011 r., realizując próbę napisania epilogu jego historii i przybliżenia sylwetek ostatnich mieszkańców [Czepas 2015].

Po omówieniu zarysu historii prac badawczych podejmijmy próbę odpowiedzi na pytanie, czy ich wyniki przełożyły się lub przyczyniły do powstania na obszarze Polski środkowej placówek muzealnych chroniących tradycyjne budownictwo chłopskie?

Warto przypomnieć w tym momencie, że myśl o stworzeniu skansenu pokazującego walory architektury chłopskiej z terenu Łowickiego narodziła się już w okresie międzywojennym [Brzostowski 1972: 55-56; por. Pytlińska-Spiss 1989: 197]. Duże muzeum na wolnym powietrzu, w ramach którego miała znaleźć swoją reprezentację chłopska architektura z różnych regionów Polski środkowej powstać miało w mieście Łodzi (na Młynku - ostatecznie utworzono tylko część rekreacyjną stanowiącą obecnie Park na Młynku) [zob. np. Zawistowicz-Adamska, Lech 1964; Lech 1967, rycina na stronie 85]. Wśród zamierzeń, których niestety nie udało się zrealizować znalazł się plan utworzenia placówki skansenowskiej przy Muzeum w Tomaszowie Mazowieckim im. Antoniego hr. Ostrowskiego [Zawistowicz-Adamska, Lech 1964: 35].

Pierwszą zakończoną powodzeniem inicjatywą na tym polu było utworzenie z początkiem lat 60. ubiegłego wieku skansenu prezentującego walory budownictwa regionu łowickiego, który powstał w centrum miasta Łowicza przy Muzeum w Łowiczu. W następnych dekadach tj. w latach 70. i 80. XX wieku udało się doprowadzić do powstania Sieradzkiego Parku Etnograficznego oraz nadal wzbogacanego o nowe obiekty Łowickiego Parku Etnograficznego.

Przez długi czas wydawać by się mogło, że rozwój nowych placówek muzealnych związanych z ochroną chłopskiej architektury w Polsce środkowej został definitywnie zakończony. Stało się jednak inaczej. Otóż

\footnotetext{
${ }^{3}$ Miejmy na uwadze, że chłopskie budownictwo o ścianach wniesionych z gliny nie występowało tylko w Chorkach. Na terenie Łęczyckiego miało ono bowiem szerszy zasięg terytorialny, co wyraźnie podkreśla Bożenna Paszkowska-Wróblewska w swoim opracowaniu. Po glinę jako surowiec budowlany sięgano także w przypadku budownictwa dworskiego, o czym przekonuje udokumentowany przez autorkę dwór w łęczyckiej wsi Siemszyce (Paszkowska-Wróblewska 1969: 151, ryc. 8).
} 
w pierwszych latach XXI wieku podjęto uwieńczone sukcesem działania, w wyniku, których udało się uratować in situ ostatnią zagrodę tzw. tatarską w Radomsku (zlokalizowaną w części dawnego Stobiecka Miejskiego). Jednym z sygnałów o możliwości ostatecznego zaniku takich zagród był artykuł autorstwa Katarzyny Filarowskiej, który opublikowano w 2003 r. w Biuletynie Towarzystwa Przyjaciół Muzeum w Radomsku [zob. Filarowska 2003]. Ostatecznie w 2011 r. miasto Radomsko po remoncie przekazało zagrodę Muzeum Regionalnemu im. Stanisława Sankowskiego w Radomsku. Jakie informacje możemy przeczytać na temat zagrody? Cytuję:

Jedyna w tej części Polski zagroda tatarska zbudowana w 1875 r. przez cieślę Adama Gałwę, przebudowana po II wojnie światowej. Dom w zagrodzie „tatarskiej” usytuowany był szczytem do drogi. Składał się z sieni, izby i komory. Za komorą znajdowały się stajnia i obora, dalej była stodoła. Od strony drogi, do domu przylegała szopa - wozownia z chlewikiem dla drobiu i drwalnią. Zabudowania szopy wraz ze ścianą szczytową domu, zajmowały szerokość placu i tworzyły zamkniętą ścianę zewnętrzną zagrody. Zwarta zabudowa oraz brak okien w domu od strony drogi świadczą o obronnej funkcji zagrody. Zagrodę „tatarską” zamieszkiwała jedna rodzina, czasem wraz ze starymi rodzicami. Zagrody takie przestano budować już przed I wojną światową. Jedną z głównych przyczyn zanikania tego typu budownictwa były liczne pożary nękające Stobiecko. W dwudziestoleciu międzywojennym zaczęto rozbierać najstarsze zniszczone obiekty całkowicie lub częściowo. Domy budowano z grubych bali sosnowych pod podwaliny podkładano kamienie polne - największe na rogach. Podwaliny tworzyły progi w drzwiach, a od strony drogi przedłużały się w próg furtki. Na podwalinach spoczywało 7-8 grubych bali tworzących ściany. Dachy pokrywano słomą. Domy od strony drogi miały dach przyczółkowy, wysunięty przed ścianę na wystających końcach górnych belek ścian nazywanych „wystawką”. Radomszczańska Chata Tatarska znalazła się wśród dziesięciu laureatów trzeciej edycji regionalnego plebiscytu, przeprowadzonego przez serwis naszemiasto.pl — „Perły w Koronie Województwa Łódzkiego 2010”. Zabytek, zrekonstruowany przy dużym wysiłku Miasta i znaczącym wsparciu Urzędu Marszałkowskiego w Łodzi, znalazł się w bardzo zacnym gronie obiektów wyróżnionych jako atrakcje turystyczne [http://www.radomsko.pl/zagroda-tatarska,m,mg,17,35,107,116.html, data odczytu: 10.09.2018].

Warto zauważyć, że wyżej przytoczone dane na temat budowy zagrody opracowano na podstawie ustaleń dokonanych przez Bożennę Paszkow- 
ską-Wróblewską. Zatem to, co zapisano na kartach muzealnego periodyku, udało się szeroko upowszechnić za pośrednictwem współczesnych kanałów przekazu informacji przy okazji tworzenia placówki in situ. Obecnie Zagroda Tatarska jest udostępniona dla zwiedzających, organizowane są na jej terenie również imprezy kulturalne, takie jak: wystawy czasowe, koncerty, pikniki, warsztaty rzemieślnicze i plastyczne itp. [http://muzeum.radomsko.pl/wakacjez-tradycja-w-zagrodzie-tatarskiej, data odczytu: 10.09.2018].

Drugą placówką, która powstała w początkach XXI w. jest Łęczycka Zagroda Chłopska w Kwiatkówku. Stanowi ona część Muzeum Archeologicznego i Etnograficznego w Łodzi. Jej powstanie było by niemożliwe, $\mathrm{z}$ uwagi na niemal całkowity brak zachowanych w terenie oryginalnych obiektów, bez odwołania się do wyników badań prowadzonych przez Bożennę Paszkowską-Wróblewską w Łęce i Chorkach. Ostatecznie formułując założenia programowe placówki, zdecydowano się na zaprezentowanie tradycyjnej architektury chłopskiej z regionu łęczyckiego, ze szczególnym uwzględnieniem budownictwa glinianego. Powstała zatem trzybudynkowa zagroda, na którą składa się: wzniesiony z gliny dwuizbowy dom z przelotową sienią, gliniany trójwnętrzny budynek inwentarski z szopą na torf pod jednym dachem oraz wzniesiona $\mathrm{z}$ drewna stodoła o dwóch sąsiekach i jednym boisku. Budynki uzupełniają elementy małej architektury w postaci studni z żurawiem, piwnicy, gnojownika oraz ogrodzeń. Wyposażenie zagrody ilustruje warunki życia średniozamożnej rodziny chłopskiej na łęczyckiej wsi w okresie międzywojennym. Na całość skansenowskiego założenia składa się także część rzemieślniczo-przemysłowa, która złożona jest z wiatraka kozłowego, olejarni i kuźni [szerzej na ten temat zob.: Chlebowska 2013a, 2013b; Chlebowska, Czepas 2015; Czepas 2013, 2014a, 2014b, 2015, 2018a, 2018b, 2018c]. Łęczycka Zagroda Chłopska została otwarta dla zwiedzających w 2013 r. W programie jej działania w sezonie turystycznym trwającym od początku kwietnia do końca października cyklicznie organizowana jest: majówka, Dzień Dziecka i obchody Nocy Świętojańskiej. W latach ubiegłych miały miejsce także obchody Europejskich Dni Dziedzictwa oraz Festiwal pt. Igrzyska Gier Dawnych. Program działania skansenu jest stale poszerzany, a przykład tego stanowi wydarzenie zorganizowane w czerwcu 2019 r. dotyczące obrzędu weselnego. Ważnym elementem działalności placówki są wystawy czasowe udostępniane zwiedzającym w ramach inauguracji sezonu turystycznego oraz z okazji obchodów Nocy Świętojańskiej, a ostatnio, jak powiedziano 
wyżej, Wesela. W skansenie prowadzone są również lekcje i warsztaty oraz plenery malarskie ${ }^{4}$ [Chlebowska, Czepas 2015: 247-252, fot. 10-12; Czepas 2018a; 2018c: 201-205].

Powstanie w ostatnich latach oddziałów placówek muzealnych wzbogaciło dotychczasową mapę Polski środkowej o nowe punkty skansenowskie. Stało się to równo po pięciu dekadach od zakończenia badań terenowych w radomszczańskim Stobiecku i wsiach na terenie Łęczyckiego. Dodać należy, dla pełności obrazu ukazanej wyżej sytuacji, że w pierwszych dekadach XXI stulecia powstało jeszcze kilka innych placówek prezentujących budownictwo z terenu Polski środkowej m.in. Zagroda Młynarska w Uniejowie, Skansen Rzeki Pilicy w Tomaszowie Mazowieckim czy Żywy Skansen Centrum Folkloru Polskiego w Nagawkach. Nie są to jednak placówki o statusie muzeum.

Na zakończenie niniejszego opracowania należy zadać pytanie, czy prowadzenie badań z ramienia placówki muzealnej nad wiejskim budownictwem jest nadal uzasadnione?

Próbując udzielić odpowiedzi, zauważyć wypada, że zdecydowaną większość systematycznych prac badawczych dotyczących tradycyjnego budownictwa chłopskiego w Polsce środkowej wykonano do połowy lat siedemdziesiątych XX w. W następnych dekadach nastąpił z różnych przyczyn znaczny spadek liczby realizowanych prac terenowych, chociaż w pewnej mierze Karty Ewidencyjne Zabytków Architektury i Budownictwa tzw. białe karty sporządzał nadal Wojewódzki Urząd Ochrony Zabytków. Również zespół etnograficzny Muzeum Archeologicznego i Etnograficznego w Łodzi — badano także budownictwo - prowadził prace terenowe w Klonowej i Jasieniu ${ }^{5}$, powstały ponadto gminne ewidencje zabytków.

\footnotetext{
${ }^{4}$ Informacje o wydarzeniach odbywających się w Łęczyckiej Zagrodzie Chłopskiej są podawane w ramach zakładki strony internetowej Muzeum Archeologicznego i Etnograficznego w Łodzi. Zob. http://www.maie.lodz.pl/pl/skansen/.

${ }^{5}$ Prace badawcze przeprowadzono w ramach grantu pt. „Trwałość kulturowa w społecznościach lokalnych na przykładzie wybranych wsi z terenu Polski środkowej”. Badania terenowe zrealizowano w latach 1994-1995 we wsi Klonowa na terenie Sieradzkiego oraz w latach 1996-1997 w Jasieniu w Rawskiem. Wyniki badań zostały zaprezentowane w dwóch numerach Serii Etnograficznej „Prac i Materiałów Muzeum Archeologicznego i Etnograficznego w Łodzi”, które ukazały się drukiem w 2001 i 2004 r. Należy szczególnie podkreślić, że wymienione wyżej wsie stały się wówczas ponownie przedmiotem badań prowadzonych przez zespół etnograficzny Muzeum Archeologicznego i Etnograficznego w Łodzi. Prace pod kierunkiem prof. Kazimiery Zawistowicz-Adamskiej przeprowadzono bowiem w latach 1953-1956 w Jasieniu, a w latach 1956-1957 (materiały uzupełniające gromadzono w 1958 roku) w Klonowej. Ich efekty zostały ogłoszone drukiem w pierwszym,
} 
Warto również mieć na uwadze, że proces rozwoju budownictwa wiejskiego nie zatrzymał się w połowie XX w., lecz trwał dalej i trwa nadal. W jego efekcie, nie będące dotychczas przedmiotem szerszych badań, domy mieszkalne, zabudowania gospodarcze i inwentarskie z pierwszych powojennych dekad zachowane w oryginalnym stanie są coraz mniej liczne w środowisku wiejskim. Wskutek modernizacji budynków mieszkalnych szczególnie ich elewacje i wystrój wnętrz ulegają bezpowrotnemu zatarciu. Na podstawie obserwacji zauważyć można, że wymieniane są poszycia dachowe - pokrycie papą przestaje być wykorzystywane - drewniane drzwi i okna zastępuje się wykonanymi z tworzywa, nieotynkowane ceglane elewacje ścian ociepla się zakładając warstwę izolacyjną. Tak samo dzieje się w przypadku młodszych domów pochodzących np. z lat 70. XX w. Przeobrażeniu uległy też już niektóre, lub prawdopodobnie ulegną w niedalekiej przyszłości dalsze, całe podłódzkie wsie np. Krzywiec czy Rąbień. Można sądzić, że zmiany nie będą dotyczyć tylko poszczególnych obiektów architektonicznych, lecz obejmą wszystkie elementy wiejskiego krajobrazu kulturowego.

Nieco na marginesie zauważmy także, że wskutek rozwoju dużych inwestycji przemysłowych na obszarze Polski środkowej z krajobrazu okolic Bełchatowa zniknęły w ostatnich dekadach całe wsie np. Grabek, Młynki, Parchliny, Kuców czy Wola Grzymalina. Prace terenowe w Bełchatowskiem w związku z planowaną budową Kopalni Węgla Brunatnego „Bełchatów” prowadzono m.in. z ramienia ówczesnej Katedry Etnografii (aktualnie Instytut Etnologii i Antropologii Kulturowej) Uniwersytetu Łódzkiego oraz Muzeum Archeologicznego i Etnograficznego w Łodzi w latach sześćdziesiątych XX wieku [zob. np. Mulkiewicz-Goldbergowa 1964: 53-59; także: Lechowa 1966: 5], inwentaryzacyjne zaś we wsiach na tym obszarze prowadziło dekadę później Polskie Towarzystwo Ludoznawcze.

Reasumując, wydaje się zatem, że znajdujemy się obecnie w podobnej sytuacji jak nasi poprzednicy ponad pół wieku temu. Wtedy właśnie zaczynał się zanik tradycyjnego budownictwa chłopskiego wznoszonego przed II wojną światową, który drastycznie przybrał na sile w latach 70. XX wieku wskutek przemian kulturowo-cywilizacyjnych wsi. Dziś coraz większym przeobrażeniom ulega budownictwo wiejskie pochodzące z pierwszych

drugim i trzecim numerze Serii Etnograficznej „Prac i Materiałów Muzeum Archeologicznego i Etnograficznego w Łodzi” w 1957, 1958 i 1960 roku. 
dekad po II wojnie światowej, toteż potrzeba jego systematycznej dokumentacji wydaje się być uzasadniona.

Przy tej okazji zapytać należy, czy również budownictwo wiejskie powstałe po 1989 r. i wciąż wznoszone mogłoby stać się przedmiotem zainteresowań badawczych? Zapis myśli o dokumentacji ówcześnie nowo budowanych domów odkryć możemy w zasobach Archiwum Etnograficznego Muzeum Archeologicznego i Etnograficznego w Łodzi. Wśród licznych materiałów związanych z tradycyjnym budownictwem chłopskim stanowiących pokłosie badań kierowanych przez Józefa Lecha znajduje się pięć teczek zatytułowanych „Inwentaryzacja uproszczona budynku mieszkalnego (współczesnego)”. Na materiały te składa się dokumentacja rysunkowa, opisowa i fotograficzna domów mieszkalnych ze wsi Mierzyce i Toporów z terenu Wieluńskiego. Została ona sporządzona w 1972 r., a jej przedmiotem są obiekty wzniesione na przestrzeni lat 1956-1966. Były to murowane domy wzniesione według gotowych projektów, które wprowadzono w pierwszych dekadach po II wojnie światowej ${ }^{6}$.

Należy zatem wyrazić nadzieję, że realizacja systematycznych badań nad wiejskim budownictwem przeprowadzona z ramienia placówki muzealnej mogłaby przyczynić się do wzbogacenia bazy źródłowej dotyczącej budownictwa wiejskiego z okresu po II wojnie światowej i posiadanych kolekcji muzealiów, organizacji wystaw np. poświęconych wystrojowi wnętrz domów, a także realizacji nowych, śmiałych inicjatyw skansenowskich w przyszłości.

\section{Bibliografia}

\section{Brzostowski Stanisław}

1972: Z dziejów parków etnograficznych (skansenów) w Polsce, [w:] Muzea skansenowskie w Polsce, kom. red. S. Błaszczyk et al., Poznań: Państwowe Wydawnictwo Naukowe.

\section{Chlebowska Barbara}

2013a: Obiekt Zamiejscowy Muzeum Archeologicznego i Etnograficznego w Łodzi - część etnograficzna, „Rocznik Muzeum Wsi Mazowieckiej w Sierpcu”, t. IV.

2013b: Poskładane z okruchów. Uwagi na temat pracy nad wyposażeniem wnętrza domu mieszkalnego w Łęczyckiej Zagrodzie Chłopskiej, „Zeszyty Wiejskie”, z. XVIII.

\footnotetext{
${ }^{6}$ Inwentaryzacja uproszczona budynku mieszkalnego (współczesnego), nr inw.: 1726/19; 1726/27; 1726/30; 1726/51; 1726/61. Archiwum Etnograficzne Muzeum Archeologicznego i Etnograficznego w Łodzi.
} 


\section{Chlebowska Barbara, Czepas Piotr}

2015: Łęczycka Zagroda Chłopska. Powstanie i funkcjonowanie w pierwszych latach, „Acta Scansenologica”, t. XI.

\section{Czajkowski Jerzy}

2011: Dom drewniany w Polsce. Tysiąc lat historii, Kraków: Zakład Wydawniczy "NOMOS«.

\section{Czepas Piotr}

2013: Olejarnia z miejscowości Mnich-Kolonia, pow. Kutno, woj. łódzkie jako przykład drobnej działalności przemysłowej w środowisku wiejskim, „Zeszyty Wiejskie”, z. XVIII.

2014a: Olejarnia Władysława Malesy w Mszadli, pow. Skierniewice, woj. łódzkie jako dokument techniki i życia społecznego mieszkańców wsi, „Zeszyty Wiejskie”, z. XIX.

2014b: Założenia programowe części etnograficznej Obiektu Zamiejscowego Muzeum Archeologicznego i Etnograficznego w Łodzi, „Rocznik Muzeum Wsi Mazowieckiej w Sierpcu”, t. V.

2015: Ostatni gliniany dom z Chorek w powiecie łęczyckim i jego mieszkańcy, „Zeszyty Wiejskie”, z. XXI.

2018a: Łęczycka Zagroda Chłopska w Kwiatkówku, „Kwartalnik Historii Kultury Materialnej”, R. LXVI, nr 2.

2018b: Kuźnia z Porszewic, powiat Pabianice, województwo łódzkie jako dokument architektury i rzemiosła wiejskiego, „Zbiór Wiadomości do Antropologii Muzealnej”, t. V. (http://zwam.ptl.info.pl/wp-content/uploads/2019/01/01_03_P-Czepas_Kuznia-z-Porszewic.pdf, data odczytu: 10.09.2018).

2018c: Działalność Zespołu Działów Etnograficznych Muzeum Archeologicznego i Etnograficznego w Łodzi (2008-2016), „Prace i Materiały Muzeum Archeologicznego i Etnograficznego w Łodzi. Seria Etnograficzna”, nr 35.

\section{Filarowska Katarzyna}

2003: Budownictwo „tatarskie” w Stobiecku Miejskim, „Nasz Świat. Biuletyn Towarzystwa Przyjaciół Muzeum w Radomsku”, nr 4.

\section{Gladyszowa Maria}

1976: Budownictwo, [w :] Etnografia Polski. Przemiany kultury ludowej, t. I, red. M. Biernacka, B. Kopczyńska-Jaworska, A. Kutrzeba-Pojnarowa, W. Paprocka, Wrocław-Warszawa-Kraków-Gdańsk: Zakład Narodowy im. Ossolińskich — Wydawnictwo Polskiej Akademii Nauk.

\section{Grajnert Józef}

1880: Zapiski etnograficzne z okolic Wielunia i Radomska, „Zbiór Wiadomości do Antropologii Krajowej”, t. IV.

\section{Karłowicz Jan}

1884: Chata polska. Studyjum lingwistyczno-archeologiczne, „Pamiętnik Fizyjograficzny”, t. IV. 


\section{Lech Józef}

1967: Z prac nad projektowaniem łódzkiego parku etnograficznego, „Łódzkie Studia Etnograficzne”, t. IX.

1979: Tradycyjny dom chłopski ijego użytkowanie na obszarze środkowej Polski, „Prace i Materiały Muzeum Archeologicznego i Etnograficznego w Łodzi. Seria Etnograficzna”, nr 20.

\section{Lechowa Irena}

1966: Problematyka badań etnograficznych nad rzemiosłem w Grocholicach w powiecie betchatowskim, „Prace i Materiały Muzeum Archeologicznego i Etnograficznego w Łodzi. Seria Etnograficzna”, nr 10.

\section{Moszyński Kazimierz}

1967: Kultura ludowa Słowian, t. I, Kultura materialna (wyd. II), Warszawa: Książka i Wiedza.

\section{Mulkiewicz-Goldbergowa Olga}

1964: Badania etnograficzne w okręgu przemysłowym betchatowskim, „Łódzkie Studia Etnograficzne”, t. VI.

\section{Paszkowska-Wróblewska Bożenna}

1960: Budownictwo w Klonowej, „Prace i Materiały Muzeum Archeologicznego i Etnograficznego w Łodzi. Seria Etnograficzna”, nr 3.

1963: Budownictwo „tatarskie” w Stobiecku Miejskim, „Prace i Materiały Muzeum Archeologicznego i Etnograficznego w Łodzi. Seria Etnograficzna”, nr 7.

1964: Tradycyjne budownictwo w Łęce, „Prace i Materiały Muzeum Archeologicznego i Etnograficznego w Łodzi. Seria Etnograficzna”, nr 8.

1965: Budownictwo mieszkalne w Łaznowie, „Prace i Materiały Muzeum Archeologicznego i Etnograficznego w Łodzi. Seria Etnograficzna”, nr 9.

1969: Gliniane domy w Chorkach, pow. Łęczyca, „Prace i Materiały Muzeum Archeologicznego i Etnograficznego w Łodzi. Seria Etnograficzna”, nr 13.

\section{Piaścik Franciszek}

1932: Zbiory Sekcji Budownictwa Ludowego Zakładu Architektury Polskiej i Historii Sztuki Politechniki Warszawskiej, „Biuletyn Historii Sztuki i Kultury”, R. I, nr 1.

1935: Zbiory Sekcji Budownictwa Ludowego Zakładu Architektury Polskiej i Historii Sztuki Politechniki Warszawskiej, „Biuletyn Historii Sztuki i Kultury”, R. IV, nr 1.

\section{Piątkowska Ignacja}

1897: Poszukiwania. Chata, „Wisła”, t. XI.

\section{Pytlińska-Spiss Anna}

1989: Muzea na wolnym powietrzu w Polsce, „Etnografia Polska”, t. XXXIII, z. 2.

\section{Święch Jan}

2002: Architektura chłopska ziemi dobrzyńskiej od połowy XVIII wieku do lat czterdziestych XX wieku, Toruń: Wydawnictwo TOP KURIER.

2012: Chłopskie budownictwo zagrodowe Kujaw w XIX wieku i pierwszej połowie XX wieku, Kraków: Towarzystwo Wydawnicze „Historia Iagellonica”. 


\section{Wawrzeniecki Marian}

1898, Poszukiwania. Chata, „Wisła”, t. XII.

\section{Zawistowicz-Adamska Kazimiera}

1957: Badania etnograficzne nad regionem łódzkim, „Zeszyty Naukowe Uniwersytetu Łódzkiego”, Seria I, Nauki Humanistyczno-Społeczne, z. 5.

1959: Zakres badań etnograficznych nad regionem łódzkim. Osiągnięcia i postulaty badawcze, „Prace i Materiały Etnograficzne”, t. XIII.

1960: Badania klonowskie jako przyczynek do badań nad regionem łódzkim, „Prace i Materiały Muzeum Archeologicznego i Etnograficznego w Łodzi. Seria Etnograficzna”, nr 3.

\section{Zawistowicz-Adamska Kazimiera, Lech Józef}

1964: Łódzki park etnograficzny, „Łódzkie Studia Etnograficzne”, t. VI.

\section{Źródła niepublikowane}

Inwentaryzacja uproszczona budynku mieszkalnego (współczesnego), nr inw.: 1726/19; 1726/27; 1726/30; 1726/51; 1726/61. Archiwum Etnograficzne Muzeum Archeologicznego i Etnograficznego w Łodzi.

\section{Strony internetowe}

http://www.maie.lodz.pl/pl/skansen.

http://www.radomsko.pl/zagroda-tatarska,m,mg,17,35,107,116.html, data odczytu: 10.09.2018.

http://muzeum.radomsko.pl/wakacje-z-tradycja-w-zagrodzie-tatarskiej, data odczytu: 10.09.2018.

\section{Piotr Czepas}

\section{About the need and importance of research into traditional peasant architecture in museums (shown on the example of chosen institutions in Central Poland)}

This article attempts to address the current state of on-site research conducted by museum institutions, devoted to the issue of traditional peasant buildings. As part of the article, a review of research work undertaken in Central Poland throughout the $20^{\text {th }}$ century was carried out. The review is particularly focused on on-site research performed on behalf of the Museum of Archaeology and Ethnography in Łódź in Stobiecko Miejskie (being now part of the City of Radomsko) and in selected villages of Łęczyca region. Its output contributed to the establishment of two facilities in the first decades of the $21^{\text {st }}$ century, i.e. the Tatar Homestead and Łęczyca Peasant Homestead, which are part of the Stanisław Sankowski Regional Museum in Radomsko and the Museum of Archaeology and Ethnography in Łódź, respectively. The article also attempts to answer the question whether it is currently justified to conduct ethnographic on-site research on behalf of museums on rural buildings erected after World War II. 
Keywords: open-air museum, traditional peasant buildings, Łęczyca Peasant Homestead in Kwiatkówek, Tatar Homestead in Radomsko

Tłumaczenie na język angielski zrealizowało: Biuro Tłumaczeń Lidex - Oddział w Łodzi. 
